\title{
Research on the economic innovation of industrial design policy of "Design Promotion Center" of Taiwan Foreign Trade Association
}

\author{
Zhao Pingyuan $^{1, \mathrm{a}^{*}}$, Zhang Xiujuan ${ }^{1, \mathrm{~b}}$ \\ ${ }^{1}$ Art Management Division of Fine Arts Department, College of Arts \& Design of Jimei University, Xiamen, Fujian, China
}

\begin{abstract}
Taiwan foreign trade association have made great achievements in the macro design policy formulation and micro level communication, and the cooperation between industrial enterprises and industrial design studios and designers. Based on Taiwan's modern industrial manufacturing enterprises and the economic goal of economic structure transformation, these macro design industry development strategies and research work are effective. They have created a new era for Taiwan's industrial design to be in line with international standards and upgrade in an all-round way after the 1990s, and played an important role in shaping the overall industrial brand effect of "Taiwan Design".
\end{abstract}

\section{Introduction}

After the 1990s, the industrial design activities of the design promotion center of Taiwan foreign trade association have made great achievements in the macro design policy formulation and micro level communication, and the cooperation among industrial enterprises, industrial design studios and designers. From a strategic perspective, in 1991, the center, Taiwan Furniture Industry Association and Chongcai design fund management committee jointly held the 1991 furniture design competition; In terms of industrial design industry strategy, the "center" puts forward the idea of establishing "enterprise design alliance" in Taiwan. In terms of specific implementation strategy, it studies the design industry from two directions: furniture design and manufacturing and computer product design and manufacturing. The former is called "integrator coordinator" direction, and the design and manufacturing enterprises relying on the research are Sanguang Weida enterprise and Datong company; The latter is called "intelligent desk" direction, relying on the cooperation and development of Acer computer, beautiful enterprise and Datong enterprise. Based on Taiwan's modern industrial manufacturing enterprises and the economic goal of economic structure transformation, these macro design industry development strategies and research work are effective. They have created a new era for Taiwan's industrial design to be in line with international standards and upgrade in an all-round way after the 1990s, and played an important role in shaping the overall industrial brand effect of "Taiwan Design".

\section{Development of industrial promotion project of "Design Promotion Center".}

\section{1 "small Europe plan"}

Taiwan foreign trade association's important strategic plan for industrial design includes the "small Europe plan" issued in 1992. As an integral part, the "Taipei Design Center" set up in Dusseldorf, Germany in that year is an important measure to enhance Taiwan's industrial design. Germany is the birthplace of modern industrial design and design education. In the Post-war Western developed economies, Germany's strong industrial design ability, design awards and exhibitions have become the benchmark of global industrial design. The exchange with Germany in the field of industrial design is reflected in its active participation in the German version of the world industrial design awards, such as Red dot has become the direction and trend of industrial design in Taiwan in the 1990s" The Asian base of "small Europe plan" is set up in Osaka, Japan. In 1994, the "Taipei Design Center" was set up in Osaka. As the planning department for the macro development of Taiwan's industrial design, the association of foreign trade and the Taiwan Industrial Design Association, another important planning organization, formulated two important "overall plans for improving industrial design capability" and "training plans for industrial design talents". On the basis of these plans, the "second five year plan" and the 1995-1999 plan for implementing the two plans were formulated in 1993.

\footnotetext{
$\mathrm{a}^{*}$ Corresponding author: kittyzhangxiu@126.com

bzpy032003@126.com
} 
From the micro level, in addition to strategic industrial design policy formulation and research, the meticulous work and rich projects of the center at the micro level are also the true portrayal of Taiwan's industrial design situation in the 1990s. We can see from the contents of several "design month" and "cross design camp" activities in 1991: in 1991, tidex91, namely "design month" activity, was sponsored by the foreign trade association, with the theme of "Taipei International Design and self created brand". We once again see the grand transformation behind the micro topics. Beyond the hard elements of capital, technology and production capacity, the pursuit of product design and the demand for personalization and branding have become the important market segmentation elements that industrial design has to consider" The center is keen to capture this global market trend and become an academic topic of the activity. It takes the deepening of the concept of "self created brand" as a lever for Taiwan's manufacturing and design to gain access to the global market. Design exhibition projects include "Taipei International Design and self created brand exhibition".

Globalization is the most popular topic in the field of global politics, economy and industry in the 1990s. ICSID 1991 annual conference is called "promotion, professional and educational meeting", also known as PPE conference. The topic of the conference is "East meet West", The industrial design issues discussed seem to go beyond the scope of traditional industrial design and upgrade to "the educational needs of designers of tomorrow", "the environment and responsibility of designers" and "the establishment of a global network of design centers". This shows that the basic issues of Taiwan's industrial design and the strategic thinking of Taiwan's industrial design promotion agencies are always synchronized with those of the world. Accordingly, the 1991 ICSID spring board meeting Taipei was held in Taipei, which once again demonstrated the global synchronization of the industrial design strategic thinking of the design promotion center of the international trade association. In the same year, the "fourth Taipei International Cross Design camp" hosted by the "center" once again invited ten internationally renowned industrial designers to conduct "paired" design product exchange activities with nine famous industrial enterprises in Taiwan. We can see its achievements in the following 1991 "jewelry and watch design competition" and "design exhibition". In 1991, the Malaysian Institute of standards and industry held the "11th Asian Design Conference" in Kuala Lumpur and the "first international industrial design Seminar and Exhibition" in Malaysia. Taiwan also participated in the conference. Wu Guanxiong, vice chairman of the Association for the development of foreign trade, led the conference, The keynote speech "Design Promotion - policies and activities" is a review of government design management in Taiwan and an important document for us to study the course of design management in East Asia. In 1992, Taiwan also sent a delegation to attend the 17th ICSID rubiana conference. The topic of the conference "at the crossroads" clearly metaphors the development and cultural change of industrial design in the globalized world market and cultural convergence. Taiwan still accurately finds its own experience in the global design tide. "by 2020, Finland will achieve international success as a supplier of sustainable, high-quality products and services As a valuable investment, design is widely used in business and design institutions. In the future, new winners in business will benefit from the concepts of experimental methods, responsibility and feedback to nature.[1]In this paper, the design policy of Finland is used for reference to supplement the design promotion in Taiwan.

\section{2 promote the development of design through exhibition and competition}

In 1993, "the sixth Taipei International Cross Design Competition" demonstrated the maturity of the promotion mechanism of this kind of pairing and cross industrial design. Ten Taiwanese industrial enterprises participated in the competition. The pairing and cross situation is as follows: Taiwan Electric Appliance Co., Ltd. and German designer Matthias Christoph designed "series of household lighting products" in cooperation; Taiwan Baishi Stationery Co., Ltd. cooperates with Italian designer Paolo Pagani to design pen products; Taiwan Tongzi Industrial Co., Ltd. cooperates with shigenori ASAKURA, a Japanese designer, to design "electric toys". In 1994, the cross pairing design situation of the 7th Taipei International Cross Design camp was as follows: Taiwan Baosheng Co., Ltd. cooperated with designer malard Harald marauardt to design "new stationery series". Taiwan foreign trade association's industrial design promotion activities at the micro level are also reflected in the holding of high-level international design awards. In 1992, Taiwan's participation in the Hanover if award in Germany and the establishment of Dusseldorf's "Taipei Design Center" of the "small Europe project" are undoubtedly important incentives. In 1992, the cfta held a special international industrial design competition - "Taipei public telephone booth International Design Competition" with Taiwan's "Natural Science Museum". The camp of the judges reflected the pursuit of international level: Zheng Yuanjin, director of cfta's Design Promotion Center; Han Baode, director of "Natural Science Museum"; Zheng Yuanjin, director of cfta's Design Promotion Center; Han Baode, director of "Natural Science Museum"; The American judge is Mr. ward Peter woodwing, former president of IDSA and famous professor of Rhode Island School of design. The German judge is Stefen Lengyel, Professor of Design School of Eisen University and head of vdid; The Japanese judge is Yoh Tanaka, head of Tanka design company in Japan. The winners of this design competition embody the global design concern, including Japanese designer Takashi Kuwabara and British designer Dennis s.l.chen; Chen Mingshi, a rising designer in Taiwan, won the prize. Similar to the special design competition, there is the "1993 future vehicle design competition" jointly held by the foreign trade association and Japan Yamaba Locomotive Company. 
In terms of the impact on the peak of international industrial design and the right to speak in the field of industrial design, the highest achievement of the association is to help win the 1995 ICSID annual conference in Taiwan. The above theme industrial design exhibition is the steps and preparation for the association to enter the core area of industrial design and gain recognition. In 1993, there were eight corresponding large-scale design exhibitions, including "excellent product design and selection Exhibition", "new generation design competition and Exhibition", "future vehicle design competition and Exhibition", "achievements exhibition of industrial bureau's plan to enhance industrial design capability", "achievements exhibition of Taibei cross design camp", "professional design resources Exhibition", etc "Handicraft products selection Exhibition" and the above "public telephone booth design exhibition". Just before the ICSI was held in Taiwan, the cfta established the first post-war CAID studio in Taiwan, which means that with the advent of the era of global industrial design, computer-aided industrial design and manufacturing transformation, the cfta once again stands at the forefront of the tide and takes a long-term view to lead the industrial design industry to embrace the new world of global industrial design.

\section{The growth of industrial design in early postwar Taiwan}

\section{1 the germination of early industrial design in Taiwan after World War II}

The establishment of the "Design Promotion Center" of the foreign trade association marks the formation and maturity of the global market-oriented industrial design in Taiwan. In the development process of Taiwan's industrial design after World War II, the clue of the development status before the establishment of the "Design Promotion Center" is clear. In the gradual development of industrial design in East Asia after World War II, Japan took the lead. As early as 1952, "Japan Industrial Design Association" was established. At that time, the mainland still set up the "Arts and Crafts Research Office" in the Department of practical art of the East China branch of the Central Academy of Fine Arts in the following year, but the gap between the design concepts we knew was self-evident. In the "era of American aid" that we have repeatedly described, the cultivation of Taiwan Design by developed countries in Europe, America and Japan also took place in the following years" The "American aid" also gave birth to Taiwan's "China" productivity and Trade Center, the most important industrial design management and promotion organization in the early postwar period. In the field of modern industrial design education that sprouted in Taiwan, the early important "private Mingzhi Industrial College" Five-Year "industrial design department" was also born.

\section{2 existing problems}

The early industrial design education in Taiwan overlapped with art and craft education seriously, which was not conducive to the development of modern industrial design. In 1965, Taipei Polytechnic College divided the newly established "industrial design" into two groups of "architectural design" and "product design", which is a great progress. In 1978, for the first time in the history of Taiwan's contemporary product design, Taipei Polytechnic College added "furniture design group" to its college education. Achievements of industrial design education in Colleges and Universities: in 1977, the student design work "twist car" of Taipei polytechnic school won the gold award of Geneva invention exhibition. In 1980, ICSID held the "First International Furniture Design Exhibition" in Poland. The student work "laminated chair" of furniture design group of Taipei Polytechnic College was selected into the Polish international furniture design competition. In 1984, the Institute of mechanical engineering of Chenggong University established the "industrial design group"; In 1986, Taiwan universal technical college set up "industrial design department".

\section{3 significance of "Design Promotion Center"}

Since the 1990s, industrial design education in Taiwan has entered an important era of comprehensive promotion, international integration and scale development; It is also a critical period for design concept to acquire modern connotation. This year, Taipei Polytechnic College formulated an overall industrial design upgrading plan, namely "Taiwan North District industrial design talent training and research development center". The corresponding professional colleges set up the industrial design magazine "design information room"; In the same year, Chenggong University also set up a similar "Taiwan Southern industrial design talent training and research development center" and founded "win strategy". In 1990, industrial design education in the Institute flourished all over the world. The following departments were born successively: Industrial Design Department of Taiwan Private Huafan Institute of technology; Department of industrial design, Taiwan Private Hechun Polytechnic College; The Institute of industrial engineering, School of management, Taiwan Jiaotong University established the "industrial design group"; Chenggong University set up "Design Institute"; Daye University, funded by Taiwan's Haneda automobile company, is dedicated to the cultivation of automobile design and technical talents. Its "industrial design department" enrolls students from all over Taiwan. The progress of industrial design education also benefits from the unremitting invitation of developed countries to Taiwan for high-end design lecture tour and guidance: in 1993, Martin darbyshire, an important British Industrial designer of tangerrine design concept, and Douglas barger, a designer of DB design, were invited to give lectures in Taiwan; In 1994, Taiwan Industrial Design Association invited John Paul kusz, 
President of American Industrial Design Association, to Taiwan Chenggong University for industrial design methodology training. From the theme of "environmental protection design method", we can see that the concept of "sustainable" and "green design", avant-garde design concepts and world-wide design trends are pouring into Taiwan in time. In the same year, Taiwan's "designers' Association" and "interior designers' Association" invited Prof. Ronald Beckman, a world-famous furniture designer and creator of the concept of "systematic furniture design", to Taiwan to jointly hold the "office series furniture design Seminar", with large-scale participation of Taiwan's design enterprises, furniture production enterprises and industrial design education circles. In 1994, Philip Mai felip, President of the International Industrial Design Association, went to Taiwan. At that time, the main working body of the Taiwan government responsible for joining ICSID was the "ICSID working group of the Taiwan foreign trade association", which studied the 1995 Taipei conference. Design 2005, the first edition of national design policy issued by the Finnish government in 2000, points out that design is not only an industry skill, but also a clean and efficient human knowledge resource. The input of knowledge resources can gradually reduce and replace the consumption and dependence on natural resources, and make the economy achieve sustainable development.[2] the two ideas coincide.

\section{4 future strategy and Modern Enlightenment of "Design Promotion Center"}

In June, 2003, the Ministry of economy of the Republic of China invited a number of units including the Ministry of economy industry bureau and the Bureau of international trade to assist in the establishment of Taiwan Creative Design Center (TDC), which is located in the software technology park of South Hong Kong. The original of creative design center is the design promotion center of foreign trade association established in 1979. The transformation of the achievements of the design promotion center witnessed the rapid development of cultural and creative industries, provided successful experience for the development of relevant industries in mainland China, and guided the direction of future development. At present, cultural and creative industries are being paid attention to globally, because it represents the development direction of the future society and new economic growth points. Cultural and creative industry is a highly integrated industry of culture, economy and science and technology, with special value orientation, and has become an important indicator to measure the comprehensive development level and competitiveness of a city or even a country. In March, 1993, the State Council issued the notice of the State Council approving and transferring the thinking of the national tertiary industry development plan, which included the cultural industry in the national development planning for the first time. In 1998, the Ministry of culture established the "cultural industry division", marking the official recognition of cultural industry by the Chinese government. The proposal of the tenth five year plan, which was held at the Fifth Plenary Session of the 15th National Congress of the Communist Party of China on October 11, 2000, proposed to improve the policy of cultural industry and promote the development of cultural industry. This is the first time that "cultural industry" is put forward in the official document of the CPC Central Committee, which marks the beginning of targeted macro policy guidance in China. Then, in February2003, China Printing Group Co., Ltd. established China cultural industry development group company, which is not only the transformation and development of state-owned enterprises, but also the concrete embodiment of national policies. In July, 2009, the State Council issued the first special plan for cultural industry in China, the revitalization plan for cultural industry, which indicates that the state has begun to concentrate on the development of cultural industry. From 2010 to 2015, the major central documents and national strategic planning have paid more and more attention to cultural industry every year, and pushed them to a more important position. In November 2016, the Ministry of finance established the cultural division, which will provide support for the country in cultural reform and development related financial policies. In contrast, the historical development of Fujian Cultural and creative industries also follows similar track. The first is that local governments respond to the call of the central government to develop the tertiary industry, including cultural industries. However, with the development of economy, especially after entering WTO, it is found that the products of "knowledge economy" can play a competitive role in Fujian Province, Not just cultural production and services. Therefore, the concept of "creative industry" came out at the beginning of this century.Finland takes the lead in environmental protection and recycling of waste materials. Finland's technology of using waste glass to process new building materials has been popularized all over the world. In 2001, about 40000 tons of waste glass were recycled every year, which brings a broad prospect for the utilization of waste glass. [3]

\section{Conclusion}

If we regard the 1995 Taipei annual meeting of the International Industrial Design Association held in Taiwan as an important node, we can conclude that the modern transformation of Taiwan's industrial design from postwar to the 21 st century is closely related to the efforts of the two major promoting institutions; In fact, the two institutions were committed to the macro goals of Taiwan's economic transformation and political breakthrough after the war. Around the beginning of the 21st century, Taiwan's industrial designers have repeatedly won design awards from Germany, other European countries, the United States and Japan, which have shocked the Asia Pacific industrial design circles; The work of the two "associations" started before and after Taiwan's "US aid" and the hidden clues of the efforts to declare international existence and political 
identity in the late 1970 s cannot but have a direct or indirect impact on industrial designers; And in the industrial design of modern progress.At present, artificial intelligence has been able to compose complete music, learn to sketch animals and objects, and generate complex images from photography. AI even learned new fashion design and began to write scripts for films and stage plays(4) In the tourism industry, the application of artificial intelligence not only brings tourists a better experience, but also helps the tourism destination to monitor the tourist data in real time, so as to better carry out the tourist flow management of scenic spots.(5)

\section{Author information}

Zhao Pingyuan: Male, born in 1970 in Jingchuan, Gansu, China; associate professor of College of Arts \& Design of Jimei University; PhD. with research interest in design management and design industry.

\section{References}

1. KÄHÖNEN H, CHEN Chaojie. Research on the Evolution and Development of Design Innovation System in Finland [C]//WANG Xiaohong. China Innovation Design Development Report (2016). Beijing: Social Science Press, 2016.

2. CHEN Chaojie, FANG Hai. The Finnish Design Based on Sustainable Development Theory[J]. Packaging Engineering, 2014，35 (6) : 69-72.

3. Global outlook of renewable resources research, issue 6: 40 .

4. Word Ecomomic Forum \& Mckinsey.Creative Disruption:The Impact of Emerging Technologies on the Creative Economy. 2018..http://www.weforum, org/whitepapers/creative-disruption-the-impact-of-e merging-technologies-on-the-creative-economy.

5. UNWTO.Intetnational Tourism Highlights 2019.https://www.e-unwto.org/doi/pdf/10.18111/978 9284421152. 